\title{
Impact of Soybean Front Line Demonstrations
}

\author{
N. D. Deshmukh ${ }^{*}$, S. K. Deshmukh ${ }^{1}$ and R. S. Bhople ${ }^{3}$ \\ ${ }^{1}$ Extension Education, College of Agriculture, Badnapur Dist Jalna, India \\ ${ }^{2}$ Extension Education, KVK, Karda Washim, India \\ ${ }^{3}$ Department of Extension Education, Post Graduate Institute, Dr.PDKV, Akola, India \\ *Corresponding author
}

\section{A B S T R A C T}

\begin{abstract}
In order to ascertain the impact of soybean front line demonstrations in terms of change in knowledge and adoption of soybean production technology on demonstrator and non demonstrator farmers, the present study was carried out by selecting 73 demonstrator and 70 non-demonstrator farmers from 14 villages in the jurisdiction of Krishi Vigyan Kendra, Karda of Risod Panchayat Samiti of Washim district in Maharashtra state. The demonstrator farmers were found to be high in productivity of soybean crop, use of sources of information, extension contact, cosmopoliteness, scientific orientation and economic motivation than non-demonstrator farmers. The front line demonstrations created significantly greater impact on demonstrator farmers than non-demonstrator farmers. In case of demonstrator farmers, land holding, area under soybean crop, experience of soybean cultivation, social participation, socio-economic status, sources of information and extension contact established positive relationship with the impact of soybean front line demonstrations. Regarding non-demonstrator farmers, education, land holding, social participation and socio-economic status established positive and significant relationship with the impact of soybean front line demonstrations.
\end{abstract}

\section{Introduction}

In Maharashtra state, soybean is being cultivated since last 30 years. However, the farmers are not very well aware about improved production technology of soybean and therefore, having low productivity. It leads to low income per unit area. The efforts are underway to popularize improved protection and production technology and increase the productivity of soybean by conducting demonstrations on soybean production technology.
Field demonstrations provide complete learning experience to farmers by taking part in laying out and maintaining them. They also serve as relaying centers of dissemination of technology to the surrounding farmers who are actually not involved in the process of laying out demonstrations. Much of the success of field demonstrations depends on the extent to which demonstrator farmers acquire information on technology, process it and disseminate same to others (Dixit et. al., 1998). 
Indian Council of Agricultural Research has, therefore, introduced the concept of 'Firstline Demonstration' under the "Oilseed Technology Mission” during 1990-91. Later on these demonstrations termed as "front line demonstrations". The field level demonstrations conducted under the close supervision of the scientists are called front line demonstrations because the technologies are demonstrated for the first time by the scientists before it being fed to the main agricultural extension system. Front line demonstrations are definitely helpful by showing the beneficial results of newly developed technology in terms of production and protection measures. It also provide scientists with an opportunity to demonstrate the technology on actual farmer's field condition as to get direct feedback from the field so that the performance of the new technology could be further modified and improved.

In the present study, efforts were taken to know and compare the profile of soybean front Line demonstrator and nondemonstrator farmers, to ascertain the impact of soybean front line demonstrations and to explore the relationship of characteristics of demonstrator and non-demonstrator farmers with the impact of soybean front line demonstrations in terms of change in knowledge and adoption of soybean production technology.

\section{Materials and Methods}

The present study was carried out in 14 villages under the jurisdiction of Krishi Vigyan Kendra, Karda of Risod Panchayat Samiti of Washim District in Maharashtra state. Experimental design of social research was used for the investigation. All 73 demonstrator farmers from 14 villages selected as an experimental group and 5 nondemonstrator farmers from each village (70 farmers) selected as a control group, constitute the study sample of 143 respondents. The selected respondents from both experimental and control group were more or less similar in their socio economic status and having same cropping pattern. The data were collected from the respondents at their homes or farms as per their convenience with the help of structured interview schedule. The impact of soybean front line demonstrations was ascertained in terms of change in knowledge and adoption score of the respondents. A teacher made knowledge test consisting various questions related to soybean production technology demonstrated through front line demonstrations was developed and response to each question was judged as correct and incorrect and scored as one and zero, respectively and knowledge index was worked out. Regarding adoption, it was measured with the help of actual use of demonstrated soybean production technology on three continuum i.e., full, partial and no adoption and scored as two, one and zero, respectively and adoption index was worked out. Keeping in a view study objectives, collected data were statistically analysed with the help of frequency, percentage, mean, standard deviation, coefficient of correlation and ' $Z$ ' test of mean differences.

\section{Results and Discussion}

\section{Profile of demonstrator and non- demonstrator farmers}

Table 1 shows that, majority of the demonstrator farmers were young (45.21\%), educated up to high school level (43.84\%), possessed big land holding (52.05\%), having more than 2 hectare area under soybean crop $(80.83 \%)$, harvesting 13-21 quintals productivity per hectare (46.58\%) and had 4-6 years experience of soybean cultivation (69.86\%). Most of the demonstrator farmers were member of one formal organization 
(71.23\%), had upper middle socio-economic status (47.94\%), used sources of information and extension contact to the lower extent i.e., 57.53 per cent and 65.75 per cent, respectively. High level of cosmopoliteness $(58.90 \%)$ and scientific orientation $(84.93 \%)$ and medium level of economic motivation $(61.64 \%)$ were observed in case of most of the demonstrator farmers in soybean cultivation.

Table 1 also indicated that, majority of the non-demonstrator farmers were middle aged $(40.00 \%)$, educated up to high school level (47.14\%), possessed medium land holding $(40.00 \%)$, having more than 2 hectare area under soybean crop (65.72\%), harvested up to 12 quintals productivity per hectare $(50.00 \%)$ and had 4-6 years experience of soybean cultivation $(42.86 \%)$. Most of the nondemonstrator farmers were member of one formal organization (81.83\%), had upper middle socio-economic status $(52.85 \%)$, used sources of information and extension contact to the lower extent i.e., 75.71 per cent and 87.14 per cent, respectively. Medium level of cosmopoliteness (61.43\%), high level of scientific orientation (47.14\%) and medium level of economic motivation $(44.28 \%)$ were observed in case of most of the nondemonstrator farmers in soybean cultivation.

Table.1 Profile of demonstrator and non-demonstrator farmers

\begin{tabular}{|c|c|c|c|c|c|c|c|}
\hline \multirow[t]{2}{*}{$\begin{array}{l}\text { Sr. } \\
\text { No }\end{array}$} & \multirow[t]{2}{*}{ Variable } & \multirow[t]{2}{*}{ Category } & \multicolumn{2}{|c|}{$\begin{array}{l}\text { Demonstrator } \\
\text { farmers }\end{array}$} & \multicolumn{2}{|c|}{$\begin{array}{l}\text { Non- } \\
\text { demonstrator } \\
\text { farmers }\end{array}$} & \multirow[t]{2}{*}{$\begin{array}{c}\text { 'Z' } \\
\text { Value }\end{array}$} \\
\hline & & & $\begin{array}{l}\text { Freq. } \\
(\mathrm{N}=73)\end{array}$ & $\begin{array}{l}\text { Per } \\
\text { cent }\end{array}$ & $\begin{array}{l}\text { Freq. } \\
(n=70)\end{array}$ & $\begin{array}{l}\text { Per } \\
\text { cent }\end{array}$ & \\
\hline \multirow[t]{4}{*}{1} & \multirow[t]{4}{*}{ Age } & Young & 33 & 45.21 & 27 & 38.57 & \multirow[t]{4}{*}{0.693} \\
\hline & & Middle & 26 & 35.62 & 28 & 40.00 & \\
\hline & & Old & 14 & 19.18 & 15 & 21.43 & \\
\hline & & Mean & \multicolumn{2}{|c|}{40.42} & \multicolumn{2}{|c|}{41.52} & \\
\hline \multirow[t]{5}{*}{2} & \multirow[t]{5}{*}{ Education } & Primary & 07 & 09.57 & 05 & 07.14 & \multirow[t]{5}{*}{1.19} \\
\hline & & Middle & 07 & 09.57 & 12 & 17.14 & \\
\hline & & High & 32 & 43.84 & 33 & 47.14 & \\
\hline & & Collage & 27 & 36.90 & 20 & 28.57 & \\
\hline & & Mean & \multicolumn{2}{|c|}{10.32} & \multicolumn{2}{|c|}{09.71} & \\
\hline \multirow[t]{6}{*}{3} & \multirow{6}{*}{$\begin{array}{l}\text { Land } \\
\text { holding }\end{array}$} & Marginal farmers & 01 & 01.37 & 03 & 04.29 & \multirow[t]{6}{*}{1.93} \\
\hline & & Small farmers & 05 & 06.86 & 08 & 11.43 & \\
\hline & & Semi-medium & 11 & 15.07 & 10 & 14.29 & \\
\hline & & Medium farmers & 18 & 24.66 & 28 & 40.00 & \\
\hline & & Big farmers & 38 & 52.05 & 21 & 30.00 & \\
\hline & & Mean & \multicolumn{2}{|c|}{10.72} & \multicolumn{2}{|c|}{08.40} & \\
\hline \multirow[t]{5}{*}{4} & \multirow{5}{*}{$\begin{array}{l}\text { Area under } \\
\text { soybean crop }\end{array}$} & Up to 0.40 ha & 03 & 04.11 & 00 & 00.00 & \multirow[t]{5}{*}{1.24} \\
\hline & & 0.41 to 1.00 ha & 02 & 02.73 & 05 & 07.14 & \\
\hline & & 1.01 to $2.00 \mathrm{ha}$ & 09 & 12.33 & 19 & 27.14 & \\
\hline & & Above 2.00 ha & 59 & 80.83 & 46 & 65.72 & \\
\hline & & Mean & \multicolumn{2}{|c|}{04.86} & \multicolumn{2}{|c|}{04.15} & \\
\hline \multirow[t]{2}{*}{5} & \multirow{2}{*}{$\begin{array}{l}\text { Productivity } \\
\text { of soybean }\end{array}$} & Up to 12 & 24 & 32.88 & 35 & 50.00 & \multirow[t]{2}{*}{$8.67 * *$} \\
\hline & & 13 to 21 & 34 & 46.58 & 21 & 30.00 & \\
\hline
\end{tabular}




\begin{tabular}{|c|c|c|c|c|c|c|c|}
\hline & \multirow[t]{2}{*}{ crop (qt/ha) } & \multirow{2}{*}{\begin{tabular}{|l|} 
Above 21 \\
Mean
\end{tabular}} & \multirow{2}{*}{\multicolumn{2}{|c|}{\begin{tabular}{l|l}
15 & 20.55 \\
16.69 &
\end{tabular}}} & \multicolumn{2}{|c|}{\begin{tabular}{|l|l|}
14 & 20.00 \\
\end{tabular}} & \\
\hline & & & & & & & \\
\hline \multirow[t]{4}{*}{6} & \multirow{4}{*}{$\begin{array}{l}\text { Experience } \\
\text { of soybean } \\
\text { cultivation }\end{array}$} & Up to 3 years & 07 & 09.57 & 16 & 22.81 & \multirow[t]{4}{*}{ 2.64* } \\
\hline & & 4 to 6 years & 51 & 69.86 & 30 & 42.86 & \\
\hline & & Above 6 years & 15 & 20.55 & 24 & 34.29 & \\
\hline & & Mean & \multicolumn{2}{|c|}{04.94} & \multicolumn{2}{|c|}{05.84} & \\
\hline \multirow[t]{5}{*}{7} & \multirow[t]{5}{*}{$\begin{array}{l}\text { Social } \\
\text { participation }\end{array}$} & $\begin{array}{l}\text { Member of one } \\
\text { informal organisaton }\end{array}$ & 00 & 00.00 & 00 & 00.00 & \multirow[t]{5}{*}{1.79} \\
\hline & & $\begin{array}{l}\text { Member of one formal } \\
\text { organisaton }\end{array}$ & 52 & 71.23 & 57 & 81.83 & \\
\hline & & $\begin{array}{l}\text { Office bearer of } \\
\text { informal organisaton }\end{array}$ & 18 & 24.66 & 13 & 18.57 & \\
\hline & & $\begin{array}{l}\text { Office bearer of } \\
\text { formal organisaton }\end{array}$ & 03 & 04.11 & 00 & 00.00 & \\
\hline & & Mean & \multicolumn{2}{|c|}{03.32} & \multicolumn{2}{|c|}{03.18} & \\
\hline \multirow[t]{6}{*}{8} & \multirow{6}{*}{$\begin{array}{l}\text { Socio- } \\
\text { economic } \\
\text { status }\end{array}$} & Low & 00 & 00.00 & 00 & 00.00 & \multirow[t]{6}{*}{1.64} \\
\hline & & Lower middle & 01 & 01.36 & 04 & 05.71 & \\
\hline & & Middle & 31 & 42.46 & 28 & 40.00 & \\
\hline & & Upper middle & 35 & 47.94 & 37 & 52.85 & \\
\hline & & High & 06 & 08.21 & 01 & 01.42 & \\
\hline & & Mean & \multicolumn{2}{|c|}{31.57} & \multicolumn{2}{|c|}{30.50} & \\
\hline \multirow[t]{4}{*}{9} & \multirow{4}{*}{$\begin{array}{l}\text { Sources of } \\
\text { information }\end{array}$} & Low & 42 & 57.53 & 53 & 75.71 & \multirow[t]{4}{*}{$3.95 * *$} \\
\hline & & Medium & 27 & 36.98 & 14 & 20.00 & \\
\hline & & High & 04 & 05.47 & 03 & 04.28 & \\
\hline & & Mean & \multicolumn{2}{|c|}{20.52} & \multicolumn{2}{|c|}{13.48} & \\
\hline \multirow[t]{4}{*}{10} & \multirow{4}{*}{$\begin{array}{l}\text { Extension } \\
\text { contact }\end{array}$} & Low & 48 & 65.75 & 61 & 87.14 & $4.98 * *$ \\
\hline & & Medium & 18 & 24.65 & 09 & 12.85 & \\
\hline & & High & 07 & 09.58 & 00 & 00 & \\
\hline & & Mean & & & & & \\
\hline 11 & Cosmopolite & Low & 11 & 15.06 & 13 & 18.57 & 2.96* \\
\hline & ness & Medium & 19 & 26.02 & 43 & 61.43 & \\
\hline & & High & 43 & 58.90 & 14 & 20.00 & \\
\hline & & Mean & & & & & \\
\hline 12 & Scientific & Low & 01 & 01.36 & 16 & 22.86 & $6.139 * *$ \\
\hline & orientation & Medium & 10 & 13.69 & 21 & 30.00 & \\
\hline & & High & 62 & 84.93 & 33 & 47.14 & \\
\hline & & Mean & & & & & \\
\hline 13 & Economic & Low & 01 & 01.36 & 25 & 35.71 & $5.013 * *$ \\
\hline & motivation & Medium & 45 & 61.64 & 31 & 44.28 & \\
\hline & & High & 27 & 36.98 & 14 & 20.00 & \\
\hline & & Mean & & & & & \\
\hline
\end{tabular}

* Significant at 0.05 level of probability

** Significant at 0.01 level of probability 
Table.2 Distribution of demonstrator and non-demonstrator farmers according to impact of soybean front line demonstrations

\begin{tabular}{|c|c|c|c|c|c|c|}
\hline \multirow[t]{2}{*}{ Sr. No } & \multirow[t]{2}{*}{ Impact Category } & \multicolumn{2}{|c|}{ Demonstrator farmers } & \multicolumn{2}{|c|}{ Non-demonstrator farmers } & \multirow[t]{2}{*}{ 'Z' Value } \\
\hline & & $\begin{array}{l}\text { Frequency } \\
(\mathrm{N}=73)\end{array}$ & Per cent & $\begin{array}{l}\text { Frequency } \\
(n=70)\end{array}$ & Per cent & \\
\hline \multirow[t]{4}{*}{1} & Low & 04 & 05.48 & 06 & 08.57 & \multirow[t]{4}{*}{ 4.70* } \\
\hline & Medium & 44 & 60.27 & 57 & 81.63 & \\
\hline & High & 25 & 34.25 & 07 & 10.00 & \\
\hline & Mean score & \multicolumn{2}{|c|}{127.50} & \multicolumn{2}{|c|}{112.88} & \\
\hline
\end{tabular}

* Significant at 0.05 level of probability

Table.3 Relationship between characteristics of demonstrator and non-demonstrator farmers and impact of soybean front line demonstrations

\begin{tabular}{|l|l|c|c|}
\hline \multirow{2}{*}{$\begin{array}{l}\text { Sr. } \\
\text { No. }\end{array}$} & Variable & \multicolumn{2}{|c|}{$\begin{array}{c}\text { Coefficient of correlation } \\
\text { Non-demonstrator } \\
\text { farmers }\end{array}$} \\
\hline 1. & Age & 0.116 & -0.071 \\
\hline $\mathbf{2 .}$ & Education & 0.194 & $0.257^{* *}$ \\
\hline $\mathbf{3 .}$ & Land holding & $0.505^{*}$ & $0.234^{* *}$ \\
\hline $\mathbf{4 .}$ & Area under soybean crop & $0.259^{* *}$ & -0.06 \\
\hline $\mathbf{5 .}$ & Productivity of soybean crop & 0.017 & 0.046 \\
\hline $\mathbf{6 .}$ & Experience of soybean cultivation & $0.226^{* *}$ & 0.028 \\
\hline $\mathbf{7 .}$ & Social participation & $0.261^{* *}$ & $0.251^{* *}$ \\
\hline $\mathbf{8 .}$ & Socio-economic status & $0.343^{*}$ & $0.431^{*}$ \\
\hline $\mathbf{9 .}$ & Sources of information & $0.821^{*}$ & 0.223 \\
\hline $\mathbf{1 0}$ & Extension contact & $0.735^{*}$ & 0.217 \\
\hline $\mathbf{1 1}$ & Cosmopoliteness & 0.022 & -0.163 \\
\hline $\mathbf{1 2}$ & Scientific orientation & 0.095 & 0.035 \\
\hline $\mathbf{1 3}$ & Economic motivation & 0.067 & -0.038 \\
\hline
\end{tabular}

**significant at $1 \%$ level of probability

*significant at $5 \%$ level of probability

Calculated ' $Z$ ' value on the basis of mean score of each variable shows that, the demonstrator farmers were found to be significantly high in productivity of soybean crop, use of sources of information, extension contact, cosmopoliteness, scientific orientation and economic motivation than non-demonstrator farmers. The nondemonstrator farmers had comparatively more experience of soybean cultivation than that of demonstrator farmers.
Impact of soybean front line demonstrations on demonstrator and non demonstrator farmers

It could be noted from Table 2 that, majority of the demonstrator farmers $(60.27 \%)$ had medium impact of soybean front line demonstrations in terms of change in knowledge and adoption of soybean production technology. However, 34.25 per cent of the farmers were found in high impact 
category and only 05.48 per cent farmers were in low impact category.

In case of non-demonstrator farmers, it was observed that great majority of them $(81.63 \%)$ had medium level of impact of soybean front line demonstrations in terms of change in knowledge and adoption of soybean production technology, while, 10.00 and 08.57 per cent of them were observed in high and low impact category, respectively.

The mean impact index of demonstrator farmers was found significantly higher than that of non-demonstrator farmers. This may be due to addition in their knowledge and increase in adoption about soybean production technology demonstrated through front line demonstrations. These findings are in line with the findings of Bonde et al., (2002).

\section{Relational analysis}

Table 3 revealed that, in case of demonstrator farmers land holding, area under soybean crop, experience of soybean cultivation, social participation, socio-economic status, sources of information and extension contact established positive and significant relationship with the impact of soybean front line demonstrations.
Regarding non-demonstrator farmers, the variables like education, land holding, social participation and socio-economic status established positive and significant relationship with the impact of soybean front line demonstrations.

Thus, with increase in land holding, area under soybean crop, experience of soybean cultivation, social participation, socioeconomic status, sources of information and extension contact, there had been increase in impact of soybean front line demonstrations on demonstrator farmers.

\section{References}

Bonde, S.B., R.S. Bhople and P.S. Shinde, (2002). Impact of vegetable cultivation training organised by Krishi Vigyan Kendra on vegetable growers. Maharashtra J. Extn. Educ., XXI (1): 18-21.

Dixit Shreenath, K.R.M. Swamy, N. Yadukumar and E.V.V. Bhaskararao, (1998). Field demonstrations in promoting cashew production technology. Indian J. Extension Educaion XXXIV (3\&4):74.

\section{How to cite this article:}

Deshmukh, N. D., S. K. Deshmukh and Bhople, R. S. 2020. Impact of Soybean Front Line Demonstrations. Int.J.Curr.Microbiol.App.Sci. 9(09): 833-838.

doi: https://doi.org/10.20546/ijcmas.2020.909.105 